\title{
INDIAN MEDICINAL PLANTS USEFUL IN TREATMENT OF GOUT: A REVIEW FOR CURRENT STATUS AND FUTURE PROSPECTIVE
}

\author{
BHUPINDER KAPOOR, GAGANDEEP KAUR, MUKTA GUPTA, REENA GUPTA*
}

Department of Pharmaceutical Chemistry, School of Pharmaceutical Sciences, Lovely Professional University, Phagwara, Punjab, India. Email: reenaph14@gmail.com

Received: 3 May 2017, Revised and Accepted: 27 July 2017

\section{ABSTRACT}

Objective: The objective of this review is to collect and document information on the Indian medicinal plants with anti-gout potential.

Methods: Bibliographic investigation was carried out by consulting worldwide scientific databases, analyzing Ayurvedic text books and research journals. The search terms were "gout," "uric acid," "hyperuricemia," "xanthine oxidase (XO) inhibitor and uricosuric." Herbal keywords included "herbal medicine," "medicinal plant," "natural products," "phytomedicine" and "phytotherapy."

Result and Conclusion: Medicinal plants have been used to treat various ailments since ancient times; hence, ethnobotanical investigations play an important role in pharmacological studies. In India, traditional medicines are being practiced for the treatment of gout and other rheumatic disorders from ancient time. This review provides a comprehensive summary of 130 Indian plants which have been mentioned in ancient literature or used traditionally for the treatment of gout. Out of these, 41 plants have been reported to possess XO inhibitory activity. Further, isolated phytoconstituents having promising XO inhibitor activity are also included in this review. Although a variety of medicinal plants with anti-gout potential have been found in the literature, there is limited information on evaluation of anti-gout activity of isolated phytoconstituents. The current review contains a detailed discussion of the potential of medicinal plants for treatment of gout.

Keywords: Gout, Xanthine oxidase inhibitor, Uricosuric agents.

(C) 2017 The Authors. Published by Innovare Academic Sciences Pvt Ltd. This is an open access article under the CC BY license (http://creativecommons. org/licenses/by/4. 0/) DOI: http://dx.doi.org/10.22159/ajpcr.2017.v10i11.20170

\section{INTRODUCTION}

Gout is an inflammatory joint disease, associated with an elevated uric acid level in blood which further leads to the deposition of urate crystals in the joints and kidneys followed by painful inflammation, gouty arthritis, and uric acid nephrolithiasis [1-3]. Xanthine oxidase (XO) is responsible for oxidation of hypoxanthine to xanthine and finally xanthine to uric acid $[4,5]$. Over activity of this enzyme and increased intake of dietary food rich in nucleic acids (e.g. meat, leguminous seeds) impair renal excretion of uric acid and result in hyperuricemia and gout [6-11].

In India, approximately $0.12-0.19 \%$ population is affected by gout, and its prevalence is more in men aged above 50 years [12,13]. The prevalence of gout is less in premenopausal women as estrogen hormone helps in urate clearance [13]. Hyperuricemia is the key predictor for the development of gout. Uric acid level over $6.8 \mathrm{mg} / \mathrm{dl}$ leads to the deposition of sodium urate crystals in joints and subcutaneous tissue [14]. This disease occurs in two phase, i.e., acute phase and chronic phase. In acute phase, intermittent attacks occur that resolves spontaneously over a period of 7-10 days. The onset of acute attack is abrupt and the affected joint becomes red, swollen, warm, and tender [7]. If acute attacks are inadequately treated, it can transform to chronic tophaceous gout. Tophi develop in periarticular tissues, cartilaginous helix of ear, and tendon sheaths [15].

\section{Conventional treatment strategies and associated side effects}

Treatment of gout is either reducing the production of uric acid (XO inhibitors) or increasing uric acid excretion (uricosuric drugs) [6]. New agents such as uricase analogs and biological cytokine inhibitors have been also used for the treatment of gout $[7,8]$. Allopurinol, a commonly used XO inhibitor, has various adverse effects such as hypersensitivity syndrome, Stevens Johnson syndrome, renal toxicity, and fatal liver necrosis $[9,10]$. Gastric and renal adverse effects are common with long-term use of anti-inflammatory agents. Selective COX-2 inhibitors are less toxic than non-selective nonsteroidal anti-inflammatory drugs (NSAID's) but renal side effects are similar to conventional NSAID's. Fatal hypersensitivity syndrome, gastric disturbances and nephrotic damage are associated with the use of urate lowering drugs such as XO inhibitors and uricosuric agents. Nausea, vomiting, severe diarrhea, and kidney damage are common with the use of colchicine. Cytokine inhibitors are highly effective with very few side effects, but these drugs are extremely expensive when compared with traditional treatment [16-18].

Impact of medicinal plants

The use of plant-based drugs for the treatment of various ailments is increasing worldwide as they are considered much safer compared to synthetic drugs [19]. India is a veritable and rich emporium of medicinal and aromatic plants. India has more than 17,500 wild plant species and out of these 4000 species have medicinal value [20]. The market sales and research activities of herbal products are growing steadily [21]. As compared to allopathic drugs, herbal medicines are claimed to be non-toxic, or generally regarded as safe because they are obtained from natural origin and their reported long-term use as folk medicine [22].

In the present review, we have summarized various Indian herbal plants used for management of gout (Table 1). Medicinal plants with reported XO inhibitory activity are also discussed in Table 2. The XO inhibitory activity of isolated phytoconstituents has been carried out by various researchers and their results have been summarized in Table 3.

\section{Plant profiles}

The anti-arthritis potential of various plants has been described briefly in the following section. The discussion consists of major families to which most of these plants belong. 
Table 1: Indian medicinal plants used in the treatment of gout

\begin{tabular}{|c|c|c|c|c|}
\hline Family & Plant name & Common name & Part used & References \\
\hline Acanthaceae & Andrographis paniculata & Bhuin & Roots & [23] \\
\hline Acanthaceae & Asteracantha longifolia & Bhikshu & Roots & {$[24,25]$} \\
\hline Acanthaceae & Barleria prionitis & Barleria & Leaves & {$[25,26]$} \\
\hline Acanthaceae & Ecbolium linneanum & Blue fox tail nail dye & Whole plant & [27] \\
\hline Acanthaceae & Nilgirianthus heyneanus & Sahachara & Whole plant & [28] \\
\hline Aizoaceae & Mollugo cerviana & Parpata & Roots & {$[25,29]$} \\
\hline Amaranthaceae & Amaranthus spinosus & Mokhonkia Phak & Whole plant & [20] \\
\hline Anacardiaceae & Semecarpus anacardium & Marking-nut & Whole plant & {$[25,31]$} \\
\hline Annonaceae & Polyalthia longifolia & Devdaru & Stem bark & [23] \\
\hline Apiaceae & Adhatoda vasica & Basak & Leaves & [32] \\
\hline Apiaceae & Apium graveolens & Garden celery & Aerial parts & [33] \\
\hline Apiaceae & Coriandrum sativum & Coriander & Fruit & [9] \\
\hline Apiaceae & Petroselinum crispum & Parsley & Seeds and leaves & {$[25,34]$} \\
\hline Araceae & Acorus calamus & Boch & Leaves & [35] \\
\hline Asparagaceae & Asparagus racemosus & Shatavari & Roots & [25] \\
\hline Asteraceae & Cichorium intybus & Chicory & Whole plant & [37] \\
\hline Asteraceae & Conyza bonariensis & Flax-leaf fleabane & Whole plant & [38] \\
\hline Asteraceae & Elephantopus scaber & Mejo-jhuti & Leaves & [23] \\
\hline Asteraceae & Launaea sarmentosa & Littoral spine grass & Whole plant & [25] \\
\hline Bignoniaceae & Tecoma stans & Yellow bells & Whole plant & [39] \\
\hline Brassicaceae & Brassica oleracea & Cabbage & Leaves and roots & {$[40]$} \\
\hline Bromeliaceae & Ananas comosus & Anaros & Roots & [35] \\
\hline Caesalpiniaceae & Caesalpinia bonduc & Fever nut & Seeds & [25] \\
\hline Caesalpiniaceae & Caesalpinia sappan & Pathimughom & Heartwood & [41] \\
\hline Caesalpiniaceae & Cassia fistula & Cassia stick & Pulp & [25] \\
\hline Caesalpiniaceae & Cappris aphylla & Caper berry & - & [25] \\
\hline Cannabaceae & Cannabis sativa & Bhang & Leaves & [42] \\
\hline Capparidaceae & Cappris decidua & Amargna & Seeds & [43] \\
\hline Capparidaceae & Cappris spinosa & Capeberry & Whole plant & [44] \\
\hline Caprifoliaceae & Sambucus nigra & Elderberry & Fruits & [9] \\
\hline Celastraceae & Celastrus paniculatus & Staff tree & Seeds & {$[23,25,45]$} \\
\hline Costaceae & Costus speciosus & Keokand & Roots & [47] \\
\hline Crassulaceae & Rhodiola rosea & Rhodiola & Roots & [48] \\
\hline Cucurbitaceae & Citrullus colocynthis & Kuwabhaturi & Leaves & {$[39,49]$} \\
\hline Cucurbitaceae & Coccinia grandis & Ivy Gourd & Leaves & [6] \\
\hline Cucurbitaceae & Momordica charantia & Bitter gourd & Fruits and leaves & {$[25,50]$} \\
\hline Cupressaceae & Biota orientalis & Westmont & Leaves & {$[1]$} \\
\hline Cupressaceae & Juniperus communis & Juniper & Berries and leaves & [9] \\
\hline Cruciferae & Lepidium sativum & Garden cress & Seeds & [25] \\
\hline Euphorbiaceae & Jatropha curcas & Bhot-era & Roots & [35] \\
\hline Euphorbiaceae & Euphorbia antiquorum & Trinagular spurge & Stem & [51] \\
\hline Euphorbiaceae & Tragia involucrata & Climbing nettle & Roots & {$[42]$} \\
\hline Fabaceae & Abrus precatorius & Crab's eye & Leaves and seeds & [25] \\
\hline Fabaceae & Crotalaria burhia & Rattlepod & Leaves & [52] \\
\hline Fabaceae & Erythrina stricta & Ronga modar & Roots & {$[2]$} \\
\hline Fabaceae & Indigofera tinctora & Indigo & Whole plant & [53] \\
\hline Fabaceae & Phaseolus calcaratus & Banmungo & Whole plant & [54] \\
\hline Fabaceae & Tephrosia purpurea & Fish Poison & Roots & [55] \\
\hline Fabaceae & Trigonella foenumgraecum & Methi & Seeds & [25] \\
\hline Flacourtiaceae & Flacourtica indica & Governor plum & Bark & [25] \\
\hline Flacourtiaceae & Gynocardia odorata & Challmograa & Seeds & [25] \\
\hline Guttiferae & Mesua ferrea & Iron wood & Stamens & [25] \\
\hline Hypericaceae & Hypericum perforatum & St. Johnswort & Aerial parts & [9] \\
\hline Iridaceae & Crocus sativum & Saffron & Bulbs & [9] \\
\hline Labiatae & Ajuga bracteosa & Khurbanti & Whole plant & [56] \\
\hline Labiatae & Rosmarinus officinalis & Rosemary & Aerial parts & {$[33]$} \\
\hline Lamiaceae & Mentha canadensis & Field Mint & Roots & {$[6,36]$} \\
\hline Lauraceae & Cinnamomum zeylanicum & Ceylon cinnamon & Whole plant & [33] \\
\hline Leguminosae & Adenanthera pavonina & Coral wood & Whole plant & {$[25,57]$} \\
\hline Leguminosae & Cassia senna & Indian senna & Leaves and pods & [58] \\
\hline Liliaceae & Gloriosa superba & Glory lily & Tubers & [59] \\
\hline Loganiaceae & Strychnos nux vomica & Poison nut & Leaves & [6] \\
\hline Loranthaceae & Viscum articulatum & Mandirika jhada & Whole plant & [23] \\
\hline Lythraceae & Lagerotroemia speciosa & Pride of India & Leaves & [3] \\
\hline
\end{tabular}


Table 1: (Continued)

\begin{tabular}{|c|c|c|c|c|}
\hline Family & Plant name & Common name & Part used & References \\
\hline Malvaceae & Gossypium herbaceum & Kopah & Leaves & [35] \\
\hline Malvaceae & Hibiscus sabdariffa & Roselle & Whole plant & [10] \\
\hline Meliaceae & Swietenia mahagoni & Mahogany & Seeds & [60] \\
\hline Menispermaceae & Cocculus hirsutus & Broom creeper & Roots & [61] \\
\hline Menispermaceae & Tinospora cordifolia & Guduchi, Giloy & Whole plant & [62] \\
\hline Molluginaceae & Mollugo cerviana & Threadstem carpetweed & Whole plant & {$[63]$} \\
\hline Moraceae & Ficus bungalensis & Borgach & Leaves & [49] \\
\hline Moraceae & Ficus carica & Fig & Whole plant & [33] \\
\hline Myristicaceae & Myristica fragrans & Nutmeg & Nut & [9] \\
\hline Myrtaceae & Caryophyllus aromaticus & Clove & Flower buds & [9] \\
\hline Oleaceae & Olea europaea & Olive & Leaves & {$[4]$} \\
\hline Oleaceae & Schrebera swietenioides & Gantha karna & Roots & [35] \\
\hline Papaveraceae & Papaver rhoeas & Corn poppy & Leaves and flowers & {$[64]$} \\
\hline Papilionaceae & Uraria picta & Prishniparni & Whole plant & [25] \\
\hline Periocaceae & Hemidesmus indicus & Antamula & Roots & [65] \\
\hline Piperaceae & Piper longum & Long pepper & Fruits & {$[66,67]$} \\
\hline Piperaceae & Piper nigrum & Black pepper & Fruits & [42] \\
\hline Plantaginaceae & Plantago ovata & Aspagol & Seeds & {$[25]$} \\
\hline Poaceae & Coix lachryma-jobi & Changing & Seeds & [68] \\
\hline Poaceae & Cymbopogan citrates & Lemon grass & Leaves and stalks & [69] \\
\hline Poaceae & Imperata cylindrica & Blady grass & Roots & {$[70]$} \\
\hline Primulaceae & Primula veris & Cowslip & Flowers & [9] \\
\hline Ranunculaceae & Aconitum falconeri & Monk's hood & Roots & {$[71,72]$} \\
\hline Ranunculaceae & Aconitum violaceum & Mithi & Roots and rhizome & [25] \\
\hline Ranunculaceae & Aquilegia fragrans & Fragrant columbine & Roots & [71] \\
\hline Ranunculaceae & Delphinium denudatum & Larkspur & Roots & [25] \\
\hline Ranunculaceae & Nigella sativa & Fennel flower & Seeds & [73] \\
\hline Ranunculaceae & Ranunculus arvensis & Corn buttercup & Whole plant & {$[74]$} \\
\hline Ranunculaceae & Thalictrum foliolosum & Pitarangaa & Whole plant & [75] \\
\hline Rhamnaceae & Ziziphus jujuba & Indian jujbe & Root & {$[25]$} \\
\hline Rubiaceae & Paederia foetida & Gandhali & Leaves & [23] \\
\hline Saliaceae & Salix alba & White willow & Whole plant & [23] \\
\hline Sapindaceae & Cardiospermum halicacabum & Small balloon vine & Whole plant & [76] \\
\hline Sapindaceae & Dodonaea viscose & Hopseed & Whole plant & {$[77,78]$} \\
\hline Sapindaceae & Schleichera oleosa & Kusum & Seeds & [23] \\
\hline Scrophulariaceae & Scoparia dulcis & Broomweed & Whole plant & [25] \\
\hline Solanaceae & Capsicum annum & Pepper & Fruits & [9] \\
\hline Solanaceae & Datura metel & Angel's trumpet & Leaves & [6] \\
\hline Solanaceae & Nicotiana tobacum & Tobacco & Leaves & [25] \\
\hline Solanaceae & Physalis alkekengi & Strawberry tomato & Leaves and fruits & [79] \\
\hline Solanaceae & Physalis minima & Sunberry & Fruits & [25] \\
\hline Solanaceae & Physalis peruviana & Cape gooseberry & Whole plant & {$[25]$} \\
\hline Solanaceae & Solanum nigrum & Black nightshade & Leaves & [80] \\
\hline Solanaceae & Withania somnifera & Ashwagandha & Roots and stem & [81] \\
\hline Sterculiaceae & Pterospermum heyneanum & Barahakani & Flowers and fruits & [23] \\
\hline Thelypteridaceae & Christella parasitica & Bihdhekia & Whole plant & [82] \\
\hline Umbelliferae & Daucus carota & Carrot & Roots & [83] \\
\hline Uritaceae & Urtica dioica & Stinging nettle & Aerial parts & [9] \\
\hline Violaceae & Viola odorata & Wood violet & Aerial parts & [9] \\
\hline Verbenaceae & Premna serratifolia & Headache tree & Whole plant & [25] \\
\hline Verbenaceae & Vitex negundu & $\begin{array}{l}\text { Pochatia } \\
\text { Pon }\end{array}$ & Leaves & {$[6,35]$} \\
\hline Vitaceae & Cissus quadrangularis & Harjora lata & Stem & [35] \\
\hline Vitaceae & Vitis vinifera & Wine grape & Fruits & {$[84]$} \\
\hline Zingiberaceae & Curcuma amada & Amba & Rhizomes & {$[23]$} \\
\hline Zingiberaceae & Curcuma caesia & Kola halodhi & Rhizomes & [35] \\
\hline Zingiberaceae & Curcuma longa & Turmeric & Whole plant & [33] \\
\hline Zingiberaceae & Kaempferia parviflora & Krachai dhum & Rhizome & [85] \\
\hline Zingiberaceae & Zingiber officinale & Ginger & Rhizomes & [40] \\
\hline Zygophyllaceae & Tribulus terrestris & Gokharu & Fruits and seeds & [86] \\
\hline
\end{tabular}

\section{Acanthaceae}

A. paniculata, a widely distributed plant in India, is used topically as well as internally for the treatment of gout [90]. In traditional system of medicine, Asteracantha longifolia parts are extensively used for various ailments such as rheumatism, inflammation, jaundice, hepatic obstruction, pain, urinary infections, edema, and gout $[23,91]$. Barleria prionitis is distributed throughout the tropical regions of India, Pakistan, Sri Lanka, Philippines, Africa, and Yemen. The extract of the plant is used for massage in toothache, swellings, arthritis, and gout pains $[25,92]$. Ecbolium linneanum is widely distributed along the eastern part of India. It has been used in various ailments such as jaundice, menorrhea, rheumatism, gout, and dysuria [31]. Nilgirianthus heyneanus is a traditional Ayurvedic herb, found throughout India. The whole plant is used in nervous system diseases, pruritus, gout, and rheumatoid arthritis [32].

\section{Apiaceae}

The paste of fresh leaves of Adhatoda vasica is used in dysentery, cough, fever, bronchial congestion, gout, and muscular sprains [37]. The anti-gout potential of Apium graveolens has been evaluated on male 
Table 2: Medicinal plants with reported XO inhibitory activity

\begin{tabular}{|c|c|c|c|c|c|}
\hline Plant name (Family) & Extract & Part used & $\begin{array}{l}\text { XO inhibition } \\
(100 \mu \mathrm{g} / \mathrm{ml})(\%)\end{array}$ & $\mathrm{IC}_{50}$ & References \\
\hline Adenanthera pavonina (Fabaceae) & Methanol & Leaves & 47.15 & - & [87] \\
\hline Antigonon leptopus (Polygonaceae) & Methanol & Leaves & 59.0 & - & [87] \\
\hline Apium graveolens (Apiaceae) & $80 \%$ ethanol $\mathrm{CH}_{2} \mathrm{Cl}_{2} /$ methanol & Aerial parts & - & $\begin{array}{l}>200 \mu \mathrm{g} / \mathrm{ml} \\
>200 \mu \mathrm{g} / \mathrm{ml}\end{array}$ & [9] \\
\hline Articum lappa (Asteraceae) & Methanol & Roots & $36.35 \pm 2.72$ & - & {$[36]$} \\
\hline \multirow[t]{8}{*}{ Averrhoa carambola (Oxalidaceae) } & \multirow[t]{2}{*}{ Distilled water } & Flowers & $0.19 \pm 2.4$ & \multirow[t]{8}{*}{-} & \multirow[t]{8}{*}{ [14] } \\
\hline & & Ripe fruit peel & $1.47 \pm 0.3$ & & \\
\hline & \multirow[t]{3}{*}{$70 \%$ methanol } & Flowers & $2.46 \pm 0.6$ & & \\
\hline & & Leaves & $20.73 \pm 0.7$ & & \\
\hline & & Ripe fruit peel & $6.89 \pm 2.3$ & & \\
\hline & \multirow[t]{3}{*}{ Ethanol } & Flowers & $2.47 \pm 0.45$ & & \\
\hline & & Leaves & $23.61 \pm 0.8$ & & \\
\hline & & Ripe fruit peel & $7.11 \pm 0.9$ & & \\
\hline \multirow{2}{*}{ Blumea balsamifera (Compositae) } & Chloroform & \multirow{2}{*}{ Leaves } & \multirow{2}{*}{-} & $0.138 \pm 0.004 \mathrm{mg} / \mathrm{ml}$ & \multirow{2}{*}[47]{} \\
\hline & Petroleum ether & & & $0.516 \pm 0.003 \mathrm{mg} / \mathrm{ml}$ & \\
\hline Capsicum annum (Solanaceae) & $80 \%$ ethanol & Fruits & - & $>200 \mu \mathrm{g} / \mathrm{ml}$ & [9] \\
\hline & $\mathrm{CH}_{2} \mathrm{Cl}_{2} /$ methanol & & & $>200 \mu \mathrm{g} / \mathrm{ml}$ & \\
\hline Carica papaya (Caricaceae) & Distilled water & Leaves & $75.68 \pm 0.1$ & - & [11] \\
\hline & & Petioles & $0.45 \pm 0.4$ & & \\
\hline & & Seeds & $18.92 \pm 0.5$ & & \\
\hline & & Fruit peel & $79.28 \pm 0.2$ & & \\
\hline & & Flowers & $60.36 \pm 0.2$ & & \\
\hline & $70 \%$ methanol & Leaves & $17.52 \pm 1.6$ & & \\
\hline & & Petioles & $79.28 \pm 0.3$ & & \\
\hline & & Seeds & $18.02 \pm 0.1$ & & \\
\hline & & Fruit peel & $15.31 \pm 0.2$ & & \\
\hline & & Flowers & $72.52 \pm 0.1$ & & \\
\hline & Ethanol & Leaves & $64.41 \pm 0.2$ & & \\
\hline & & Petioles & $57.91 \pm 0.9$ & & \\
\hline & & Flowers & $19.82 \pm 0.1$ & & \\
\hline Cassia alata (Caesalpiniaceae) & Methanol & Leaves & 24.81 & - & [87] \\
\hline Cassia fistula (Cupressaceae) & Methanol & Leaves & 61.9 & - & [87] \\
\hline Chammomila recutita (Asteraceae) & $20 \%$ ethanol & Flowers & - & $>200 \mu \mathrm{g} / \mathrm{ml}$ & [9] \\
\hline & $80 \%$ ethanol & & & $141.8 \mu \mathrm{g} / \mathrm{ml}$ & \\
\hline & $\mathrm{CH}_{2} \mathrm{Cl}_{2} /$ methanol & & & $87.6 \mu \mathrm{g} / \mathrm{ml}$ & \\
\hline Cichorium intybus (Asteraceae) & Methanol & Herb & $9.16 \pm 1.59$ & - & {$[36]$} \\
\hline Coccinia grandis (Cucurbitaceae) & Aqueous & Leaves & - & $32.25 \mu \mathrm{g} / \mathrm{ml}$ & [6] \\
\hline & Hydroalcoholic & & & $21.25 \mu \mathrm{g} / \mathrm{ml}$ & \\
\hline & Methanol & & & $29.75 \mu \mathrm{g} / \mathrm{ml}$ & \\
\hline Coriandrum sativum (Apiaceae) & $20 \%$ ethanol & Fruits & - & $>200 \mu \mathrm{g} / \mathrm{ml}$ & [9] \\
\hline & $80 \%$ ethanol & & & $>200 \mu \mathrm{g} / \mathrm{ml}$ & \\
\hline & $\mathrm{CH}_{2} \mathrm{Cl}_{2} /$ methanol & & & $>200 \mu \mathrm{g} / \mathrm{ml}$ & \\
\hline Crocus sativum (Iridaceae) & $20 \%$ ethanol & Whole plant & - & $>200 \mu \mathrm{g} / \mathrm{ml}$ & [9] \\
\hline & $80 \%$ ethanol & & & $>200 \mu \mathrm{g} / \mathrm{ml}$ & \\
\hline & $\mathrm{CH}_{2} \mathrm{Cl}_{2} /$ methanol & & & $>200 \mu \mathrm{g} / \mathrm{ml}$ & \\
\hline Datura metal (Solanaceae) & Methanol & Leaves & - & $76.75 \mu \mathrm{g} / \mathrm{ml}$ & [6] \\
\hline Daucus corata (Umbelliferae) & $\mathrm{CH}_{2} \mathrm{Cl}_{2} /$ methanol & Roots & - & $>200 \mu \mathrm{g} / \mathrm{ml}$ & [9] \\
\hline Dimocarpus longam (Sapindaceae) & Distilled water & Ripe fruits & $3.59 \pm 2.1$ & - & [11] \\
\hline & & Leaves & $15.77 \pm 1.6$ & & \\
\hline & $70 \%$ methanol & Ripe fruits & $10.85 \pm 0.1$ & & \\
\hline & & Leaves & $39.42 \pm 0.3$ & & \\
\hline & Ethanol & Ripe fruits & $13.41 \pm 1.42$ & & \\
\hline & & Leaves & $46.88 \pm 1.7$ & & \\
\hline Dodonaea viscosa (Sapindaceae) & $\begin{array}{l}1 \% \mathrm{v} / \mathrm{v} \text { ethanol and } 0.1 \% \mathrm{w} / \mathrm{v} \\
\text { Tween } 80\end{array}$ & $\begin{array}{l}\text { Leaves and } \\
\text { branches }\end{array}$ & - & $>200 \mu \mathrm{g} / \mathrm{ml}$ & {$[77]$} \\
\hline Erythrina stricta (Fabaceae) & Pet ether & Roots & - & $30.2 \pm 2.2 \mu \mathrm{g} / \mathrm{ml}$ & {$[2]$} \\
\hline & Chloroform & & & $21.2 \pm 1.6 \mu \mathrm{g} / \mathrm{ml}$ & \\
\hline & Ethyl acetate & & & $44.9 \pm 1.4 \mu \mathrm{g} / \mathrm{ml}$ & \\
\hline & Residual & & & $100 \pm 3.3 \mu \mathrm{g} / \mathrm{ml}$ & \\
\hline Equisetum arvense (Equistaceae) & Methanol & Roots & $33.13 \pm 4.00$ & - & [36] \\
\hline
\end{tabular}


Table 2: (Continued)

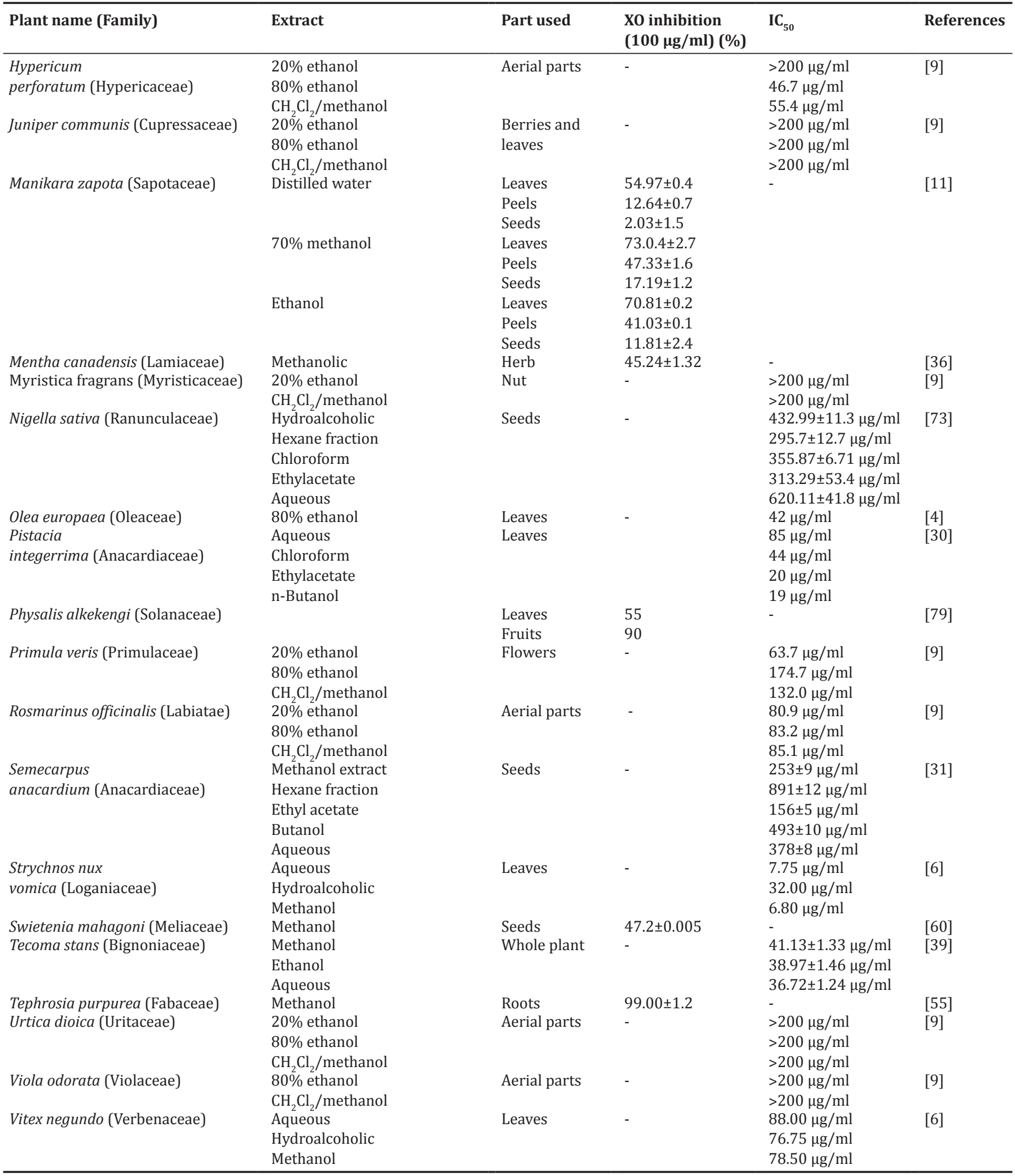

XO: Xanthine oxidase

Sprague Dawley rats and the plant extract caused significant reduction in uric acid levels in both plasma and urine [32]. The XO inhibitory potential of the plant has also been studied using methylene chloridemethanolic and two ethanolic extracts [9]. In the traditional systems of medicine, Coriandrum sativum seed extract has been used as stimulants, carminative, antispasmodics, diuretic, and anti-rheumatic. The anti- arthritic activity of the plant was evaluated using various models of arthritis, namely, formaldehyde and CFA-induced arthritis and the dose-dependent decrease in joint swelling was seen in the extracttreated groups [93]. The plant has also been evaluated for XO inhibitory activity [9]. The aqueous extract of Petroselinum crispum leaves showed significant reduction in serum uric acid levels of hyperuricemic rats [39]. 
Table 3: Isolated phytoconstituents and their XO inhibitory potential

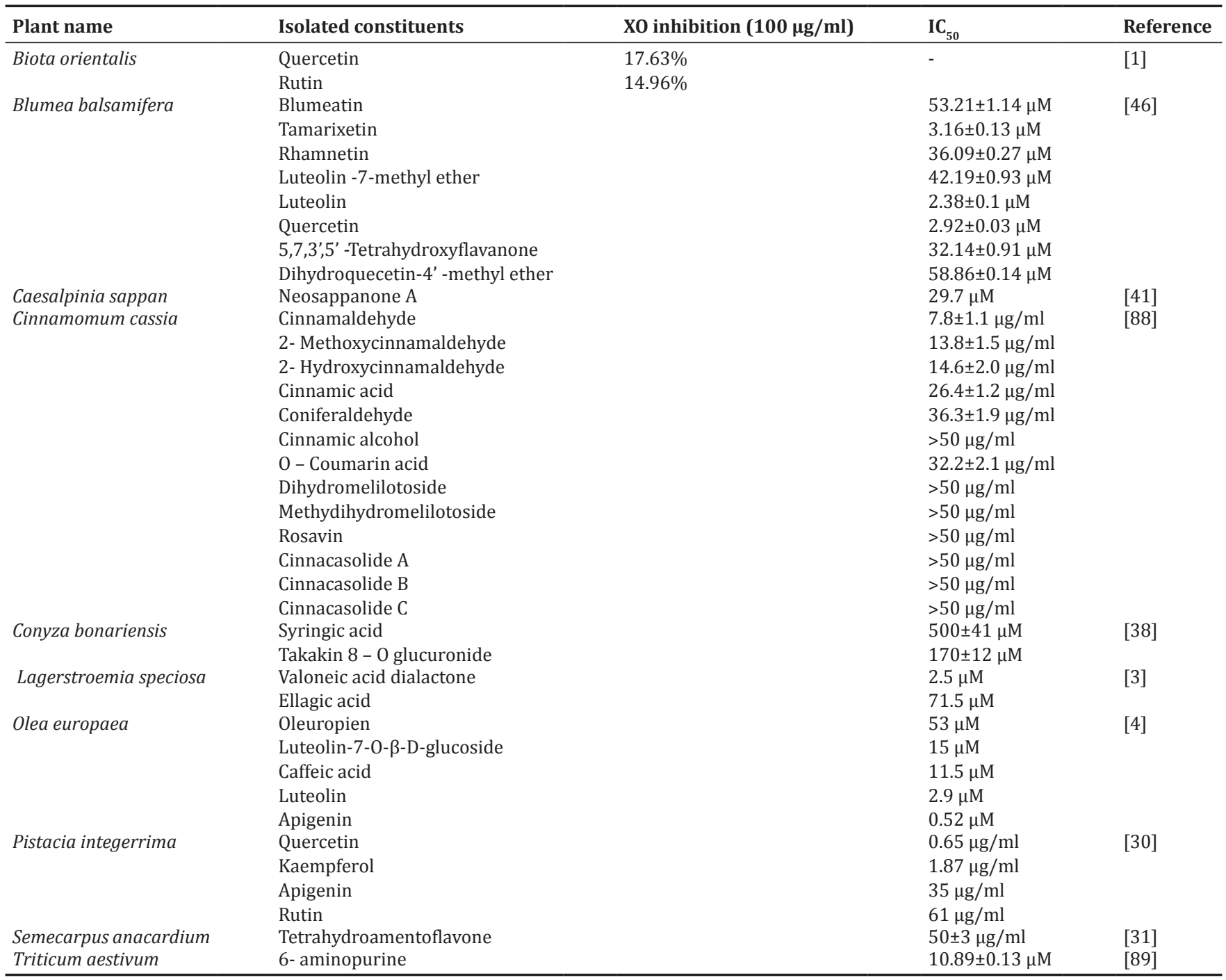

XO: Xanthine oxidase

\section{Asteraceae}

In Ayurvedic medicine, Articum lappa has been used for upper respiratory infections, pneumonia, skin problems, canker sores, arthritis, cancer, premenstrual syndrome, seborrhea, urinary tract infections, HIV, renal stone, gout, and rheumatic complaints [94]. The in vitro XO inhibitory potential of the plant has also been evaluated [41]. Chamomilla recutita is one of the important medicinal herbs found in the Indo-Gangetic plains of India [95]. The XO inhibitory potential of the plant has also been reported [9]. The roots of Cichorium intybus are used as antihepatotoxic, antiulcerogenic, anti-inflammatory, appetizer, digestive, stomachic, liver tonic, cholagogue, cardiotonic, depurative, diuretic, emmenagogue, febrifuge, alexteric, and also as tonic. It is useful in gout, hepatomegaly, inflammations, anorexia, dyspepsia, flatulence, colic, burning sensation, allergic conditions of skin, jaundice, splenomegaly, hyperdipsia, skin diseases, leprosy, strangury, amenorrhea, ophthalmia, pharangitis, vomiting, arthralgia, lumbago, asthma, general debility, AIDS, cancer, diabetes, dysmenorrhea, impotence, insomnia, splenitis, and tachycardia [42]. Decoction of leaves has been used in the treatment of jaundice, liver enlargement, gout, and rheumatism [96]. In the Indian system of medicine, Conyza bonariensis has been used as pungent, acrid, uterine sedative, and antihelmintic and is useful in the treatment of dysentery, leprosy, erysipelas, blood diseases, leucorrhea, menorrhagia, and toothache [97]. XO inhibitory potential of isolated phytoconstituents syringic acid and takakin 8-o- glucuronide has been evaluated in vitro [43]. Elephantopus scaber is used to cure skin diseases, wounds, jaundice and also used as a snakebite antidote [98]. Leaves of the plant are boiled with Schleichera oleosa oil and the paste is applied externally on gout affected body parts [23]. Launaea sarmentosa has been traditionally used as a folk remedy in India. It has been used traditionally in the treatment of jaundice, blood disorders, allergy, and gout $[25,99]$.

\section{Caesalpiniaceae}

Caesalpinia bonduc, a widely distributed plant all over the world, has been reported to possess various pharmacological activities such as anxiolytic, antinociceptive, antidiarrheal, antidiabetic, adaptogenic, antihelmintic, antiestrogenic, anti-inflammatory, antimalarial, antimicrobial, antifungal, antispasmodic, antioxidant, antiproliferative, antipsoriatic, hepatoprotective, anticonvulsant, and antifilarial [100]. It is also used in the treatment of gout [25]. Neosappanone has been isolated from C. sappan and is responsible for XO inhibitory activity, thus useful in management of gout and other joint disorder. [41]. Cappris aphylla is used in several medicinal formulations recommended for various ailments such as muscular injury, swelling, jaundice, cardiac diseases, pyorrhea, cholera, dysentery, rheumatism, constipation, stomach disorder, skin diseases, and gout [101]. Conventinally, Cassia alata has been used for treatment of ringworm, scabies, ulcers, and other skin diseases such as pruritus, eczema, and itching [102]. The XO inhibitory activity of methanolic extract of $C$. alata leaves has been reported [87]. Cassia fistula is native to southern Asia including India [103,104]. In 
traditional medicine, it has been used for various ailments such as hematemesis, pruritus, intestinal disorders, leucoderma, diabetes, gout and as antipyretic, analgesic, and laxative $[25,104]$. The XO inhibitory activity of methanolic extract of Cassia fistula leaves has been evaluated in vitro [87].

\section{Compositae}

Blumea balsamifera is widely distributed throughout Southeast Asia including India [105]. It is used in folk medicine as a stomachic, expectorant, antispasmodic, antipyretic, and diaphoretic. The XO inhibitory activities of extract and isolated flavonoids from the leaves of the plant have been evaluated in vitro [46]. Conventionally, Helianthus annuus is used in contraception and gout-related complaints $[25,106]$. Saussurea lappa is another herb widely distributed in high altitude areas of India including Kashmir, Lahaul Spiti, and Uttarakhand w[107]. The plant possesses various medicinal values such as antiulcer, anticonvulsant, anticancer, hepatoprotective, antiarthritic, antiviral, and antigout [108].

\section{Cucurbitaceae}

The crushed leaves of Citrullus colocynthis are used topically for the treatment of gout [40]. In addition to anti-gout property, the plant is also used in nose bleeding, joint pains, skin diseases, rheumatism, and gastrointestinal problems [49]. The XO inhibitory potential of methanolic extract of Coccinia grandis has been evaluated in vitro. It has also been screened for in vivo hypouricemic activity against potassium oxonate-induced hyperuricemia in mice and showed a significant decrease in the serum urate level $(3.90 \pm 0.07 \mathrm{mg} / \mathrm{dl})$ when compared to hyperuricemic control $(11.42 \pm 0.14 \mathrm{mg} / \mathrm{dl})$ [6]. Conventionally, Momordica charantia has been used in the treatment of diabetes, malaria, jaundice, leprosy, eczema, gout, piles, pneumonia, psoriasis, rheumatism, fever scabies, abdominal pain, and kidney stones. It is also used as abortifacient, antihelmintic, contraceptive, emmenagogue, galactagogue, laxative, and purgative [50].

\section{Euphorbiaceae}

Euphorbia antiquorum, Jatropha curcas, and Tragia involucrata belong to family Euphorbiaceae and are used in traditional system of medicines for treatment of gout $[25,35,109]$. Poultice of roots of $J$. curcas is made into paste and applied on the gout affected parts of the body [35]. T. involucrata is also used in the treatment of bronchitis, asthma, venereal disease, skin infections, and diabetes [109].

\section{Fabaceae}

In Indian traditional system of medicine, the seeds of Abrus precatorius have been used for the treatment of ophthalmic infections, diabetes, allergy, and kidney damage. The plant also exhibited antioxidant, antihepatitis, antimicrobial, diuretic, aphrodisiac, purgative, antifertility and anti-gout activities [29,110]. The bark and leaves of Adenanthera pavonina have been used as astringent, vulnerary, anthelmintic, and aphrodisiac. The bark is also used in colonorrhea, ulcers, pharyngopathy, gout, and rheumatism [57,111]. Crotalaria burhia, another plant belonging to same family, is used in the treatment of eczema, gout, hydrophobia, and swellings [52]. The leaves of Erythrina stricta are applied topically to treat joint pains. Bark powder is used in rheumatism, itching, epilepsy, and asthma [2]. Roots are made into paste and applied to gout affected parts of body [35]. The XO inhibitory potential of different fractions of E. stricta has been evaluated in vitro [2]. In addition to these, Indigofera tinctoria, Tephrosia purpurea, and Trigonella foenumgraecum also find application in traditional system of medicines for treatment of gout $[53,55,112]$.

\section{Malvaceae}

Conventionally, Abutilon indicum has been used as a remedy for treatment of jaundice, piles, ulcer, leprosy, and gout $[25,113]$. Leaves of Gossypium herbaceum are used as emollient, mucilaginous, hematinic, and diuretic. It is also used in gastric irritation, diarrhea, dysentery, dysuria, otalgia, and rheumatoid arthritis [114]. Poultice of leaves is mixed with its seed oil and is applied topically in gout and rheumatism due to its anti-inflammatory action [35]. The effects of Hibiscus sabdariffa has been investigated on oxonic acid-induced hyperuricemia in rats. The extract effectively inhibited hyperuricemia by increasing uricase activity and by decreasing serum uric acid levels. The XO activity was not affected by the extract [10].

\section{Ranunculaceae}

Conventionally, the roots of Aconitum falconeri have been used in paralysis, sciatica, gout, fever, rheumatism, and diarrhea [71]. Aconitum violaceum, a widely distributed plant in central Himalaya, is used to cure various ailments such as cough, asthma, inflammation, and heartrelated problems $[115,116]$. The roots of Aquilegia fragrans have been traditionally used in cystitis, gout, eczema, psoriasis, and diabetes [71]. Delphinium denudatum is widely distributed in the Himalaya region from Pakistan to Kashmir and northwest India. The roots of the plant are used for the treatment of toothache, rheumatism, syphilis, snake bite, aconite poisoning, epilepsy, and gout $[25,117]$. In traditional system of medicine, the seeds of Nigella sativa have been used as bitter, aromatic, appetizer, stimulant, diuretic, galactagogue, anthelmintic, acrid, thermogenic, carminative, purgative, and aphrodisiac. It is also used in cough, ascites, jaundice, fever, paralysis, conjunctivitis, piles, skin disease, anorexia, flatulence, abdominal disorders, diarrhea, dysentery, and hemorrhage [118]. The XO inhibitory activity of the $N$. sativa extract and different fractions of extract was evaluated in vitro [73]. Ranunculus arvensis and Thalictrum foliolosum are also used to treat gout and other joint disorders $[119,120]$.

\section{Solanaceae}

Capsicum annum is used as carminative, appetizer, and stomachic. Externally, it is used as a counter irritant in the treatment of rheumatism, lumbago, and neuralgia [121]. The XO inhibitory potential of $C$. annum has been evaluated in vitro using methylene chloride-methanolic and ethanolic extracts [9]. Datura metel is one of the most useful medicinal plant having antiseptic, narcotic, sedative, antiasthmatic, and antiulcer properties [122]. The in vitro XO inhibitory potential of D. metel leaves has been investigated using aqueous, hydroalcoholic and methanolic extracts [6]. Conventionally, Nicotiana tobacum has been used to treat skin diseases, local infections, bronchitis, asthma, and inflammation. An ointment made by simmering the leaves in lard has been employed in curing old ulcers and painful tumors [123]. Physalis alkekengi is used in the treatment of wide range of diseases including gout, inflammation, rheumatism, and kidney stones [124]. The in vitro XO inhibitory activity of the plant revealed that $0.3 \mathrm{mg} / \mathrm{ml}$ of extract exhibited inhibitory effect on XO activity [79]. Fruits of Physalis minima are used in the treatment of gout [25]. In traditional system of medicines, Solanum nigrum has been used as hepatoprotective, laxative, aphrodisiac, tonic, and diuretic. It is also used in liver cirrhosis, cancer, and gout [80]. Withania somnifera, a popular Indian medicinal plant, has been used in the Ayurvedic and indigenous medicinal system for over 3000 years [125]. It is traditionally used in treatment of rheumatism, gout, hypertension, nervine, and skin diseases [81]

\section{Zingiberaceae}

Curcuma amada, Curcuma caesia, and Curcuma longa are various species of curcuma which find applications in treatment of gout in traditional medicinal system $[33,35]$. The anti-gout activity of C. longa was evaluated on male Sprague Dawley rats and the plant extract caused significant reduction in uric acid levels in both plasma and urine [33]. The decoction of Kaempferia parviflora powder with alcohol has been reported to cure allergy, asthma, impotence, gout, diarrhea, dysentery, peptic ulcer, and diabetes [85]. Zingiber officinale is cultivated commercially in India, China, Southeast Asia, West Indies, Mexico, and other parts of the world [126]. Its rhizomes are used as hepatoprotective, aphrodisiac, antigout, sudorific, antipyretic, antiscurbutic, and food condiment [40].

\section{DISCUSSION AND CONCLUSION}

Gout is a major problem worldwide and significant advances in the treatment of gout have been made in past few decades. However, the 
current available treatment options are not completely satisfactory and associated with many side effects. In addition, due to economic problem, even today modern medical health care is out of reach of most of the population of developing countries like India. To eliminate this problem, a safe, non-toxic, and cost-effective drug is required. In this paper, we have collected the data mentioned in literature on the medicinal plants used in the treatment of gout. These plants exhibit antigout effect by different mechanisms, such as XO inhibition, uricosuric activity, anti-inflammatory activity, and antioxidant activity. In addition, plant extracts and isolated constituents which showed promising XO inhibition are also considered and most of the isolated constituents are found to be phenolic glycosides and flavonoids. Different flavonoids such as quercetin, apigenin, rutin, genistein, and astilbin also have been reported to possess XO inhibitory and uricosuric activities [127,128].

\section{Future prospective}

This review provides a comprehensive summary of medicinal plants described in ancient literature for the treatment of gout. Of these, traditional medicinal plants, only few have scientific validation. Many crude extracts have been used for the treatment of gout but their phytochemical constituent should be screened for anti-gout activity. Further, the preclinical and clinical studies of these active constituents should be performed to explore the safe drugs. Beside this, combination therapy can also be used to develop more effective agents in the treatment of gout due to their synergistic effect.

Although herbal drugs are claimed to be non-toxic or generally regarded as safe but safety concerns arises due to intrinsic toxicity, adulteration, contamination, heavy metals content, herb-drug interactions, misidentification, or poor quality control. Hence, the safety profile of these medicinal plants should be carefully assessed. The careful assessment of mechanisms and toxicity studies of herbal drugs may lead to development of safe and effective agents for management of gout which can be developed into suitable formulations.

\section{REFERENCES}

1. Zhu JX, Wang Y, Kong LD, Yang C, Zhang X. Effects of Biota orientalis extract and its flavonoid constituents, quercetin and rutin on serum uric acid levels in oxonate-induced mice and xanthine dehydrogenase and xanthine oxidase activities in mouse liver. J Ethnopharmacol 2004;93(1):133-40.

2. Umamaheswari M, Asokkumar K, Sivashanmugam AT, Remyaraju A, Subhadradevi V, Ravi TK. In vitro xanthine oxidase inhibitory activity of the fractions of Erythrina stricta Roxb. J Ethnopharmacol 2009;124(3):646-8.

3. Unno T, Sugimoto A, Kakuda T. Xanthine oxidase inhibitors from the leaves of Lagerstroemia speciosa (L.) Pers. J Ethnopharmacol 2004;93(2-3):391-5

4. Flemmiga J, Kuchtab K, Arnholda J, Rauwaldb HW. Olea europaea leaf (Ph. Eur.) Extract as well as several of its isolated phenolics inhibit the gout-related enzyme xanthine oxidase. Phytomedicine 2011;18(7):561-6.

5. Galbusera C, Orth P, Fedida D, Spector T. Superoxide radical production by allopurinol and xanthine oxidase. Biochem Pharmacol 2006;71(12):1747-52.

6. Umamaheswari M, AsokKumar K, Somasundaram A, Sivashanmugam T, Subhadradevi V, Ravi TK. Xanthine oxidase inhibitory activity of some Indian medical plants. J Ethnopharmacol 2007;109(3):547-51.

7. Punzi L, Scanu A, Ramonda R, Oliviero F. Gout as autoinflammatory disease: New mechanisms for more appropriated treatment targets. Autoimmun Rev 2012;12(1):66-71.

8. Smith HS, Bracken D, Smith JM. Gout: Current insights and future perspectives. J Pain 2011;12(11):1113-29.

9. Havlik J, Gonzalez de la Huebra R, Hejtmankova K, Fernandez J, Simonova J, Melich M, et al. Xanthine oxidase inhibitory properties of Czech medicinal plants. J Ethnopharmacol 2010;132(2):461-5.

10. Kuo CY, Kao ES, Chan KC, Lee HJ, Huang TF, Wang CJ. Hibiscus sabdariffa L. Extracts reduce serum uric acid levels in oxonate-induced rats. J Funct Foods 2012;4(1):375-81.

11. Azmi SM, Jamal P, Amid A. Xanthine oxidase inhibitory activity from potential Malaysian medicinal plant as remedies for gout. Int Food Res J 2012;19(1):159-65.
12. Smith EU, Díaz-Torné C, Perez-Ruiz F, March LM. Epidemiology of gout: An update. Best Pract Res Clin Rheumatol 2010;24(6):811-27.

13. Pande I. An update on gout. Indian J Rheumatol 2006;1:60-5.

14. Merriman TR, Dalbeth N. The genetic basis of hyperuricaemia and gout. Joint Bone Spine 2011;78(1):35-40.

15. Falidas E, Rallis E, Bournia VK, Mathioulakis S, Pavlakis E, Villias C. Multiarticular chronic tophaceous gout with severe and multiple ulcerations: A case report. J Med Case Rep 2011;5:397.

16. Keenan RT. Limitations of the current standards of care for treating gout and crystal deposition in the primary care setting: A review. Clin Ther 2017;39(2):430-41.

17. Burns CM, Wortmann RL. Latest evidence on gout management: What the clinician needs to know. Ther Adv Chronic Dis 2012;3(6):271-86.

18. Kim KY, Ralph Schumacher H, Hunsche E, Wertheimer AI, Kong SX. A literature review of the epidemiology and treatment of acute gout. Clin Ther 2003;25(6):1593-617.

19. Sahoo N, Manchikanti P, Dey S. Herbal drugs: Standards and regulation. Fitoterapia 2010;81(6):462-71.

20. Sen P, Dollo M, Choudhary MD, Choudhary D. Documentation of traditional herbal knowledge of Khamptis of Arunachal Pradesh. Indian J Tradit Knowl 2008;7:438-42.

21. Chen XW, Serag ES, Sneed KB, Zhou SF. Herbal bioactivation, molecular targets and the toxicity relevance. Chem Biol Interact 2011;192(3):161-76.

22. Zhou S, Koh HL, Gao Y, Gong ZY, Lee EJ. Herbal bioactivation: The good, the bad and the ugly. Life Sci 2004;74(8):935-68.

23. Singh H, Krishna G, Baske PK. Plants used in the treatment of joint diseases (rheumatism, arthritis, gout and lumbago) in Mayurbhanj district of Odisha, India. Rep Opin 2010;2(9):22-6.

24. Muthulingam M. Antidiabetic efficacy of leaf extracts of Asteracantha longifolia (Linn.) Nees. On alloxan induced diabetics in male albino wistar rats. Int J Pharm Biomed Res 2010;1:28-34.

25. Bansal P, Gupta V, Singh R, Chaudhary AK. Pharmacological potential of medicinal plant used in treatment of gout. Drug Invent Today 2010;2(10):433-5.

26. Ghule BV, Yeole PG. In vitro and in vivo immunomodulatory activities of iridoids fraction from Barleria prionitis Linn. J Ethnopharmacol 2012;141(1):424-31.

27. Dipankar C, Murugan S, Uma Devi P. Review on medicinal and pharmacological properties of Iresine herbstii, Chrozophora rottleri and Ecbolium linneanum. Afr J Tradit Complement Altern Med 2011;8 5 Suppl:124-9.

28. Shiddamallayya N, Yasmeen A, Gopakumar K. Medico-botanical survey of Kumar Parvantha Kukke Subramanya, Mangalore, Karnataka. Indian J Tradit Knowl 2010;9(1):96-9.

29. Parvathamma S, Shanthamma C. Antimicrobial activity of Mollugo cerviana ser. (Molluginaceae). Anc Sci Life 2000;20(1-2):11-3.

30. Ahmad NS, Farman M, Najmi MH, Mian KB, Hasan A. Pharmacological basis for use of Pistacia integerrima leaves in hyperuricemia and gout. J Ethnopharmacol 2008;117(3):478-82.

31. Arimboor R, Rangan M, Aravind SG, Arumughan C. Tetrahydroamentoflavone (THA) from Semecarpus anacardium as a potent inhibitor of xanthine oxidase. J Ethnopharmacol 2011;133(3):1117-20.

32. Hussain S, Hore DK. Collection and conservation of major medicinal plants of Darjeeling and Sikkim Himalayas. Indian J Tradit Knowl 2007;6(2):352-7.

33. Mohamed DA, Al-Okbi SY. Evaluation of anti-gout activity of some plant food extracts. Pol J Food Nutr Sci 2008;58(3):389-95.

34. Haidari F, Keshavarz SA, Mohammad Shahi M, Mahboob SA, Rashidi MR. Effects of parsley (Petroselinum crispum) and its flavonol constituents, kaempferol and quercetin, on serum uric acid levels, biomarkers of oxidative stress and liver xanthine oxidoreductase aactivity inoxonate-induced hyperuricemic rats. Iran J Pharm Res 2011;10(4):811-9.

35. Nath KK, Deka P, Borthakur SK. Traditional remedies of joint diseases in Assam. Indian J Tradit Knowl 2011;10(3):568-71.

36. Owen PL, Johns T. Xanthine oxidase inhibitory activity of Northeastern North American plant remedies used for gout. J Ethnopharmacol 1999;64(2):149-60.

37. Nandagopal S, Kumari BR. Phytochemical and antibacterial studies of chicory (Cichorium intybus L.) - A multipurpose medicinal plant. Adv Biol Res 2007;1(1-2):17-21

38. Kong LD, Abliz Z, Zhou CX, Li LJ, Cheng CH, Tan RX. Glycosides and xanthine oxidase inhibitors from Conyza bonariensis. Phytochemistry 2001;58(4):645-51.

39. Gobindappa M, Sadananda TS, Channabasava R, Raghavendra VB. 
In vitro anti-inflammatory, lipooxygenase, xanthine oxidase and acetylcholinestrase inhibitory activity of Tecoma stans (L) Juss ex Kunth. Int J Pharm Bio Sci 2011;2(2):275-85.

40. Saganuwan A. Some medicinal plants of Arabian Peninsula. J Med Plants Res 2010;4(9):767-89.

41. Nguyen MT, Awale S, Tezuka Y, Tran QL, Kadota S. Neosappanone A, a xanthine oxidase (XO) inhibitory dimeric methanodibenzoxocinone with a new carbon skeleton from Caesalpinia sappan. Tetrahedron Lett 2004; $45: 8519-22$

42. Kalita D, Bonoranjan P. Folk medicines used by the Moran of Brahmaputra Valley, Tinsukia district, Assam, India. Nat Prod Radiance 2009;8:73-6.

43. Mishra SN, Tomar PC, Lakra N. Medicinal and food value of Capparis - A harsh terrain plant. Indian J Tradit Knowl 2007;6(1):230-8.

44. Yang T, Wang C, Liu H, Chou G, Cheng X, Wang Z. A new antioxidant compound from Capparis spinosa. Pharm Biol 2010;48(5):589-94.

45. Kabnurkar RB. Phytopharmaceutical studies of the topical formulations of Celastrus paniculatus wild (Celastraceae). J Pharm Biomed Sci 2012;17:1-4

46. Nessa F, Ismail Z, Mohamed N. Xanthine oxidase inhibitory activities of extracts and flavonoids of the leaves of Blumea balsamifera. Pharm Biol 2010;48(12):1405-12

47. Jain SP, Srivastava S, Singh J, Singh SC. Traditional phytotherapy of Balaghat district, Madhya Pradesh, India. Indian J Tradit Knowl 2011;10(2):334-8.

48. Chen $\mathrm{CH}$, Chan HC, Chu YT, Ho HY, Chen PY, Lee TH, et al. Antioxidant activity of some plant extracts towards xanthine oxidase, lipoxygenase and tyrosinase. Molecules 2009;14(8):2947-58.

49. Kalita D, Bora RL. Some folk medicines from Lakhimpur district, Assam. Indian J Tradit Knowl 2008;7(3):414-16.

50. Grover JK, Yadav SP. Pharmacological actions and potential uses of Momordica charantia: A review. J Ethnopharmacol 2004;93(1):123-32.

51. Harpalani AN, Taranalli AD, Otari KV, Karadi RV, Shete RV. Antiinflammatory and anti-arthritic potential of aqueous and alcoholic extracts of Euphorbia antiquorum Linn. Pharmacologyonline 2011;2:287-98.

52. Kataria S, Shrivastava B, Khajuria RK, Suri KA, Sharma P. Pharmacognostic evaluation of Crotalaria burhia Buch - Ham. Indian J Tradit Knowl 2011;10(4):629-35.

53. Motamarri SN, Karthikeyan M, Rajasekar S, Gopal V. Indigofera tinctoria Linn - A phytopharmacological review. Int J Res Pharm Biomed Sci 2012;3:164-9.

54. Rout SD, Panda T, Mishra N. Ethno-medical plants used to cure different diseases by tribals of Mayurbhanj district of North Orissa. Ethno Med 2009;3(1):27-32

55. Nile SH, Khobragade CN. Phytochemical analysis, antioxidant and xanthine oxidase inhibitory activity of Tephrosia purpurea Linn. Root extract. Indian J Tradit Knowl 2011;2:52-8.

56. Kaithwas G, Gautam R, Jachak SM, Saklani A. Antiarthritic effects of Ajuga bracteosa Wall ex Benth. In acute and chronic models of arthritis in albino rats. Asian Pac J Trop Biomed 2012;2(3):185-8.

57. Das S, Dash S, Sahoo AC, Giri RK, Sahoo DC, Guru P. Antihyperlipidemic activity of Adenanthera pavonina Linn. Ethanolic bark extract fractions. Nat Pharm Technol 2011;1(2):1-4.

58. Al-Adhal A. The effect of Cassia angustifolia (Senna) leaves on the fasting blood sugar in a sample of mild diabetic Yemeni patients. Yemeni J Med Sci 2009;1:1-6.

59. Jana S, Shekhawat GS. Critical review on medicinally potent plant species: Gloriosa superba. Fitoterapia 2011;82(3):293-301.

60. Sahgal G, Ramanathan S, Sasidharan S, Mordi MN, Ismail S, Mansor SM. In vitro antioxidant and xanthine oxidase inhibitory activities of methanolic Swietenia mahagoni seed extracts. Molecules 2009; $14(11): 4476-85$.

61. Sangameswaran B, Jayakar B. Anti-diabetic and spermatogenic activity of Cocculus hirsutus (L) Diels. Afr J Biotechnol 2007;6(10):1212-6.

62. Reddy SS, Ramatholisamma P, Karuna R, Saralakumari D. Preventive effect of Tinospora cordifolia against high-fructose diet-induced insulin resistance and oxidative stress in male wistar rats. Food Chem Toxicol 2009;47(9):2224-9.

63. Mohammed S, Kasera PK, Shukla JK. Unexploited plants of potential medicinal value from the Indian Thar desert. Nat Prod Radiance 2004;3(2):69-74

64. Tiwari S. Plants: A rich source of herbal medicine. J Nat Prod 2008; $1: 27-35$

65. Gayathri M, Kannabiran K. Antimicrobial activity of Hemidesmus indicus, Ficus bengalensis and Pterocarpus marsupium Roxb. Indian J Pharm Sci 2009;71(5):578-81.
66. Manoj P, Soniya EV, Banerjee NS, Ravichandran P. Recent studies on well known spice Piper longum Linn. Nat Prod Radiance 2004;3(4):222-7.

67. Mamun A, Khatun MH, Islam MR, Nahar L, Shams-Ud-Doha KM, Ripa FA. Evaluation of CNS depressant and analgesic activities of the methanol extract of Piper longum Linn. Leaves. Int J Pharm Sci Res 2011;2:2874-9.

68. Singh HB, Singh TB. Plants used for making traditional rosaries in Manipur. Indian J Tradit Knowl 2005;4(1):15-20.

69. Mirghani ME, Liyana Y, Parveen J. Bioactivity analysis of lemongrass (Cymbopogan citratus) essential oil. Int Food Res J 2012;19(2):56975.

70. Jayalakshmi S, Patra A, Lal VK, Ghosh AK. Pharmacognostical standardization of roots of Imperata cylindrica Linn (Poaceae). J Pharm Sci Res 2010;2(8):472-6.

71. Joshi B, Tyagi V. Traditional knowledge and utilization of medicinal plants of Himalayan region. Nat Sci 2011;9:1-6.

72. Sharma PK, Sethi GS, Sharma SK, Sharma TK. Ethnomedical observations among the inhabitants of cold desert area of Himachal Pradesh. Indian J Tradit Knowl 2006;5(3):358-61.

73. Boudiaf K, Houcher Z, Sobhi W, Benboubetra M. Evaluation of antioxidant and anti-xanthine oxidoreductase activities of Nigella sativa Linn seeds extracts. J Appl Biol Sci 2010;4:7-16.

74. Akbulut S, Semur H, Kose O, Ozhasenekler A, Celiktas M, Basbug M, et al. Phytocontact dermatitis due to Ranunculus arvensis mimicking burn injury: Report of three cases and literature review. Int J Emerg Med 2011;4:7

75. Chattopadhyay SK, Ray AB, Slatkin DJ, Knapp JE, Schiff PL. The alkaloid of Thalictrum foliolosum. J Nat Prod 1981;44(1):45-9.

76. Nisha MC, Rajkumar S. Survey of crude drugs from Coimbatore city. Indian J Nat Prod Resour 2010;1(3):376-83.

77. Sweeney AP, Wyllie SG, Shalliker RA, Markham JL. Xanthine oxidase inhibitory activity of selected Australian native plants. J Ethnopharmacol 2001;75(2-3):273-7.

78. Venkatesh S, Reddy YR, Ramesh M, Swamy MM, Mahadevan N, Suresh B. Pharmacognostical studies on Dodonaea viscose leaves. Afr J Pharm Pharmacol 2008;2(4):83-8.

79. Hoshani M, Mianabadi M, Aghdasi M, Azim-Mohseni M. Inhibition effects of Physalis alkekengi extract on xanthine oxidase activity in different phonological stages. Clin Biochem 2011;44(13):S343.

80. Mukherjee C, Paul S, Kundu R. Comparative evaluation of antiproliferative activity of Solanum nigrum methanolic and aqueous extract on Hela, Siha and C33A cells. Int J Pharm Pharm Sci 2015;7(4):320-4.

81. Patwardhan SK, Bodas K, Gundewar S. Coping with arthritis using safer herbal options. Int J Pharm Pharm Sci 2010;2(1):1-11.

82. Patil MV, Kandhare AD, Bhise SD. Anti-inflammatory effect of Daucus carota root on experimental colitis in rats. Int J Pharm Pharm Sci 2012;4(1):337-43

83. Patil MV, Kandhare AD, Bhise SD. Pharmacological evaluation of ethanolic extract of Daucus carota Linn root formulated cream on wound healing using excision and incision wound model. Asian Pac J Trop Biomed 2012;2:S646-55.

84. Wang Y, Zhu JX, Kong LD, Yang C, Cheng $\mathrm{CH}$, Zhang $\mathrm{X}$. Administration of procyanidins from grape seeds reduces serum uric acid levels and decreases hepatic xanthine dehydrogenase/oxidase activities in oxonate-treated mice. Basic Clin Pharmacol Toxicol 2004;94(5):232-7.

85. Tewtrakul S, Subhadhirasakul S, Kummee S. Anti-allergic activity of compounds from Kaempferia parviflora. J Ethnopharmacol 2008;116(1):191-3.

86. Ashish B, Swapnil G. Hypoglycaemic effect of polyherbal formulation in alloxan induced diabetic rats. Pharmacologyonline 2011;3:764-73.

87. Apaya KL, Chichioco-Hernandez CL. Xanthine oxidase inhibition of selected Philippine medicinal plants. J Med Plants Res 2011;5(2):289-92

88. Ngoc TM, Khoi NM, Ha do T, Nhiem NX, Tai BH, Don DV, et al. Xanthine oxidase inhibitory activity of constituents of Cinnamomum cassia twigs. Bioorg Med Chem Lett 2012;22(14):4625-8.

89. Hsieh JF, Wu SH, Yang YL, Choong KF, Chen ST. The screening and characterization of 6-aminopurine-based xanthine oxidase inhibitors. Bioorg Med Chem 2007;15(10):3450-6.

90. Sharma M, Sharma A, Tyagi S, Sharma M, Sharma A. Quantitative HPLC analysis of andrographolide in Andrographis paniculata at two different stages of life cycle of plant. Acta Chim Pharm Indica 2012;2(1):1-7

91. Chauhan NS, Dixit VK. Asteracantha longifolia (L.) Nees, Acanthaceace: Chemistry, traditional, medicinal uses and its 
pharmacological activities - A review. Rev Bras Farmacogn 2010;20(5):812-17.

92. Banerjee D, Maji AK, Mahapatra S, Banerji P. Barleria prionitis Linn: A review of its traditional uses, phytochemistry, pharmacology and toxicity. Res J Phytochem 2012;6(2):31-41.

93. Nair V, Singh S, Gupta YK. Evaluation of disease modifying activity of Coriandrum sativum in experimental models. Indian J Med Res 2012; $135: 240-5$

94. Chan YS, Cheng LN, Wu JH, Chan E, Kwan YW, Lee SM, et al. A review of the pharmacological effects of Arctium lappa (burdock). Inflammopharmacology 2011;19:245-54.

95. Das M, Ram G, Singh A, Mallavarapu GR, Ramesh S, Ram M, et al. Volatile constituents of different plant parts of Chamomilla recutita L. Rausch grown in the Indo-Gangetic plains. Flavour Fragr J 2002;17:9-12.

96. Heibatollah S, Reza NM, Izadpanah G, Sohailla S. Hepatoprotective effect of Cichorium intybus on $\mathrm{CCl}_{4}$-induced liver damage in rats. Afr J Biochem Res 2008;2(6):141-4.

97. Shahwar D, Raza MA, Saeed A, Riasat M, Chattha FI, Javaid M, et al. Antioxidant potential of the extracts of Putranjiva roxburghii, Conyza bonariensis, Woodfordia fruiticosa, Senecio chrysanthemoids. Afr J Biotechnol 2012;11(18):4288-95.

98. Geetha BS, Nair MS, Latha PG, Remani P. Sesquiterpene lactones isolated from Elephantopus scaber L. Inhibits human lymphocyte proliferation and the growth of tumour cell lines and induces apoptosis in vitro. J Biomed Biotechnol 2012;2012:721285.

99. Mahesh A, Thangadurai D, Melchias G. Rapid in vitro plant regeneration from leaf explants of Launaea sarmentosa (Willd.) Sch. Bip. Ex Kuntze. Biol Res 2012;45(2):131-3.

100. Nazeerullah K, Sunil K, Pal SR, Neelam D. A pharmacognostic and pharmacological overview on Caesalpinia bonducella. Res J Pharm Biol Chem Sci 2012;3:480-96

101. Revathi P, Vani B, Sarathchandiran I, Kadalmani B, Shyam KP, Palnivel K. Reproductive toxicity of Capparis aphylla (Roth.) in male albino rats. Int J Pharm Biomed Res 2010;1(3):102-12.

102. Okoko FJ. Antimicrobial activity of aqueous and ethanol leaf extracts of Cassia alata on some clinical bacteria isolates. Int Res J Microbiol 2011;2(11):455-9.

103. Kalantari H, Jalali M, Jalali A, Mahdavinia M, Salimi A, Juhasz B, et al. Protective effect of Cassia fistula fruit extract against bromobenzeneinduced liver injury in mice. Hum Exp Toxicol 2011;30(8):1039-44.

104. Neelam C, Ranjan B, Komal S, Nootan C. Review on Cassia fistula. Int J Res Ayurveda Pharm 2011;2(2):426-30

105. Bhuiyan MN, Chowdhury JU, Begum J. Chemical components in volatile oil from Blumea balsamifera (L.) DC. Bangladesh J Bot 2009;38(1):107-9.

106. Emamuzo ED, Miniakiri SI, Tedwin EJ, Delesi KH, Precious A. Effects of ethanol extract of leaves of Helianthus annus on the fecundity of wistar rats. Asian Pac J Trop Med 2010;3:435-8.

107. Butola JS, Samant SS. Saussurea species in Indian Himalayan region: Diversity, distribution and indigenous uses. Int J Plant Biol 2010;1(e9):43-51.

108. Madhuri K, Elango K, Ponnusankar S. Saussurea lappa (Kuth root): Review of its traditional uses, phytochemistry and pharmacology. Orient Pharm Exp Med 2012;12(1):1-9.

109. Palani S, Kumar SN, Gokulan R, Rajalingam D, Kumar BS. Evaluation of nephroprotective and antioxidant potential of Tragia involucrata. Drug Invent Today 2009;1:55-60.
110. Umamaheswari M, Dhinesh S, Asokkumar K, Sivashanmugam T, Subhadradevi V, Puliyath J, et al. Anticataractic and antioxidant activities of Abrus precatorius Linn. Against calcium-induced cataractogenesis using goat lenses. Eur J Exp Bio 2012;2(2):378-84.

111. Santos IS, Da Cunha M, Machado OL, Gomes VM. A chitinase from Adenanthera pavonina L. Seeds: Purification, characterisation and immunolocalisation. Plant Sci 2004;167(6):1203-10.

112. Morani AS, Bodhankar SL, Mohan V, Thakurdesai PA. Ameliorative effects of standardized extract from Trigonella foenum-graecum L. Seeds on painful peripheral neuropathy in rats. Asian Pac J Trop Med 2012;5(5):385-90.

113. Porchezhian E, Ansari SH. Hepatoprotective activity of Abutilon indicum on experimental liver damage in rats. Phytomedicine 2005; 12(1-2):62-4.

114. Kumar SP, Singh SS, Singh NP, Mayur P. In vitro antioxidant activity of Gossypium herbaceum. Int Res J Pharm 2011;2(7):166-70.

115. Yadav S, Verma DL. Acylated flavonol glycosides from the flowers of Aconitum violaceum staph. Nat Sci 2010;8:239-43.

116. Ballabh B, Chaurasia OP. Traditional medicinal plants of cold desert Ladakh - used in treatment of cold, cough and fever. J Ethnopharmacol 2007;112(2):341-9.

117. Raza M, Shaheen F, Choudhary MI, Sombati S, Rafiq A, Suria A, et al. Anticonvulsant activities of ethanolic extract and aqueous fraction isolated from Delphinium denudatum. J Ethnopharmacol 2001;78(1):73-8.

118. Parakh PM. Nigella sativa Linn. - A comprehensive review. Indian J Nat Prod Resour 2010;1:409-29.

119. Srivastava SK. Revision of genus Ranunculus L. (Ranunculaceae) in India. Taiwania 2010;55(3):273-314

120. Joshi GC. Indigenous uses of threatened ethno-medicinal plants used to cure different diseases by ethnic people of Almora district of Western Himalaya. Int J Ayurvedic Herb Med 2012;2(4):661-78.

121. Sunil P, Sanjay Y, Vinod S. Pharmacognostical investigation and standardization of Capsicum annum L. Roots. Int J Pharmacogn Phytochem Res 2012;4(2):21-4.

122. Jamdhade MS, Survase SA, Kare MA, Bhuktar AS. Phytochemical studies on Datura metel in Marathwada region, Maharashtra. J Phytol 2010;2:46-8.

123. Sunil K, Nazeerullah K, Sayeed A, Mahaveer S, Sumit G, Amit S, et al. Comparative pharmacognostical evaluation and HPTLC fingerprinting of Nicotiana tabacum (Linn.) Root collected from different geographical regions of India. Cent Eur J Exp Biol 2012;1(1):18-25.

124. Naseri MK, Mohammadian M, Pharm ZG. Antispasmodic effect of Physalis alkekengi fruit extract. Int J Reprod Biomed 2008;6:193-8

125. Sharma V, Sharma S, Pracheta RP. Withania somnifera: A rejuvenating Ayurvedic medicinal herb for the treatment of various human ailments. Int J PharmTech Res 2011;3(1):187-92.

126. Ansari MN, Bhandari U, Pillai KK. Ethanolic Zingiber officinale $\mathrm{R}$. Extract pretreatment alleviates isoproterenol induced oxidative myocardial necrosis in rats. Indian J Exp Biol 2006;44(11):892-7.

127. Huang J, Wang S, Zhu M, Chen J, Zhu X. Effects of genistein, apigenin, quercetin, rutin and astilbin on serum uric acid levels and xanthine oxidase activities in normal and hyperuricemic mice. Food Chem Toxicol 2011;49(9):1943-7.

128. Lin CM, Chen CS, Chen CT, Liang YC, Lin JK. Molecular modeling of flavonoids that inhibits xanthine oxidase. Biochem Biophys Res Commun 2002;294(1):167-72. 